\title{
EFFECTS OF LONG-TERM STORAGE ON HUMAN SERUM ALBUMIN. I. CHROMATOGRAPHIC AND ULTRACENTRIFUGAL ASPECTS
}

\author{
By J. S. FINLAYSON, RICHARD T. SUCHINSKY AND ANN L. DAYTON \\ (From the Department of Health, Education and Welfare, National Institutes of Health, \\ Division of Biologics Standards, Bethesda, Md.)
}

(Submitted for publication June 29, 1960; accepted August 1, 1960)

The problem of the stability of normal human serum albumin during storage under various conditions is of considerable practical as well as theoretical interest. The present report covers one phase of a long-term project undertaken in our laboratory to determine what changes occur in stored albumin, the conditions affecting these changes, and the most suitable methods for detecting protein alterations.

\section{MATERIALS AND METHODS}

Samples. The samples examined were vials of commercial normal serum albumin (human) from four lots prepared for administration to patients. The preparation involved ethanol fractionation of human plasma by method 6 of Cohn and co-workers (1) and subsequent heating, in the presence of stabilizers, at $60^{\circ} \mathrm{C}$ for 10 hours to kill the serum hepatitis virus (2). For two of the lots, starting material for fractionation was liquid citrated whole plasma; for one lot it was dried, ultraviolet-irradiated plasma; for one lot it was a mixture of both types of material.

Sterile albumin samples from each of three lots were stored for 5 years at $5^{\circ}$ and $32^{\circ} \mathrm{C}$, respectively. One lot was stored for 5 years at $5^{\circ} \mathrm{C}$, whereupon the vials were divided into two groups for an additional 5 year storage period at $5^{\circ}$ and $32^{\circ} \mathrm{C}$, respectively. Most of the samples examined in this study were stored as 25 per cent protein solutions. A few samples of albumin stored in other states were also investigated.

Chromatography. Albumin solutions containing 500 $\mathrm{mg}$ of protein were diluted to $10 \mathrm{ml}$ with "starting buffer" and dialyzed in the cold for 48 to 72 hours against four changes, approximately $750 \mathrm{ml}$ each, of the same buffer. "Starting buffer" ( $\mathrm{pH}$ 8.6) was $0.005 \mathrm{M}$ in $\mathrm{H}_{3} \mathrm{PO}_{4}$ and $0.029 \mathrm{M}$ in Tris(hydroxymethyl)-aminomethane (Tris). The final buffer was $0.50 \mathrm{M}$ in both $\mathrm{H}_{3} \mathrm{PO}_{4}$ and Tris, and had a $\mathrm{pH}$ of 4.1. After dialysis the albumin samples were placed on a $2.2 \times 35 \mathrm{~cm}$ column of diethylaminoethyl (DEAE) cellulose equilibrated with starting buffer. The DEAE cellulose, containing 0.78 $\mathrm{mEq} \mathrm{N}$ per $\mathrm{g}$, was prepared by the method of Peterson and Soher (3) from powdered cellulose, 100 to 230 mesh.

${ }^{1}$ Solka-Floc, Brown Company, Berlin, N. H.
The chromatography was done at $6^{\circ} \mathrm{C}$, essentially by the method of Sober and Peterson (4). A compound concave elution gradient was obtained with a ninechambered gradient elution device ("Varigrad") of the type described by Peterson and Sober (5). Solutions placed in the chambers consisted of various amounts of final buffer diluted to $220 \mathrm{ml}$ with starting buffer. The volumes per cent of final buffer in successive chambers were $0,1.6,2.0,9.0,9.0,2.0,20.0,100$, and 100. A flow rate of $72 \mathrm{ml}$ per hour was used and $12-\mathrm{ml}$ fractions were collected. The fractions were read at $280 \mathrm{~m} \mu$ in a Beckman DU spectrophotometer.

Paper electrophoresis. Fractions from the column were placed in a negative pressure dialysis apparatus ${ }^{2}$ which permitted simultaneous concentration of the protein and dialysis against isotonic saline. During this procedure the temperature was kept low by surrounding the apparatus with ice.

Paper electrophoresis was run on the concentrated samples in a Spinco Model $\mathrm{R}$ cell using barbital buffer, $\mathrm{pH} 8.6$, ionic strength 0.075 , on Whatman $3 \mathrm{MM}$ filter paper at room temperature. Five ma per cell was applied for 18 hours, after which the strips were stained with bromphenol blue.

Ultracentrifugation. Fractions from the column, concentrated as described above, were dialyzed for 16 hours in the cold against at least 500 volumes of phosphatebuffered saline, $\mathrm{pH} 7.2$, ionic strength 0.154 . They were then centrifuged at $59,780 \mathrm{rpm}$ for 50 to 100 minutes at $20^{\circ} \mathrm{C}$ in a Spinco Model $\mathrm{E}$ ultracentrifuge at a protein concentration of approximately 1 per cent. Relative amounts of the various components were determined by planimetry following completion of the curves in the schlieren pattern. Sedimentation coefficients were reported as $s_{20}$ values.

\section{RESULTS}

While the elution profile of each sample differed to a greater or lesser extent from all others and the profiles probably represent a series of progressive changes rather than discrete types, they have been classed for convenience into four general types (Figure 1). The types exhibited by the

\footnotetext{
2 Membranfiltergesellschaft, G.m.b.H., Göttingen, Germany. Distributed by Carl Schleicher and Schuell Co., Keene, N. H.
} 


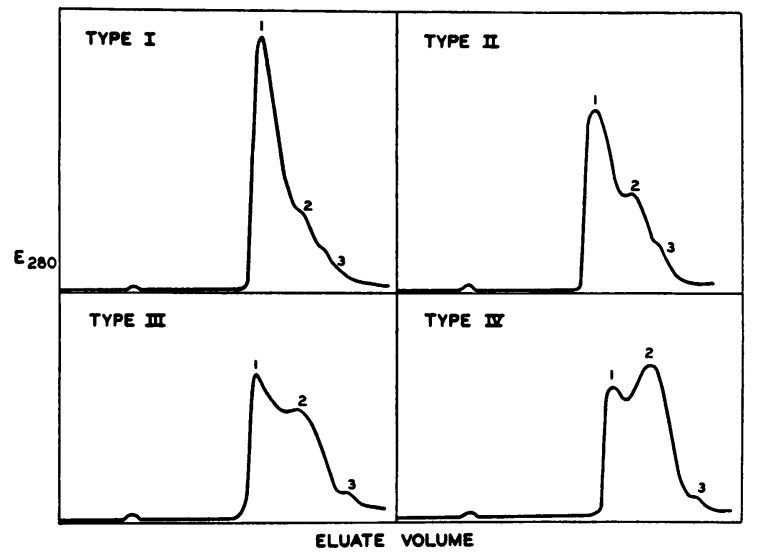

Fig. 1. Typical Chromatographic Elution Profiles of Albumin Samples.

various samples are summarized in Table I. All samples except those falling into type I showed two distinct peaks, usually with a small "foot" following them. These regions have been numbered 1, 2 and 3 (Figure 1). The small peak early in the patterns was shown to be due to acetyltryptophan which is added as a stabilizer and is not completely removed by dialysis, even after 72 hours. It was found in all the commercial samples, being absent only in the elution pattern of the fresh fraction $\mathrm{V}$ which was prepared in our laboratory by method 6 (1) and had not been stabilized or heated.

Storage of albumin, prepared from citrated whole plasma, for 5 years at $5^{\circ} \mathrm{C}$ resulted in only minimal alterations in chromatographic behavior (Table I). This was true whether it was stored as a 5 or a 25 per cent protein solution. On the other hand, after storage at $5^{\circ} \mathrm{C}$ of albumin from ultraviolet-irradiated dried plasma, or from a mixed source of irradiated dried and liquid plasma, or after storage for an additional 5 years of albumin from citrated whole plasma, a considerable quantity of material appeared in region 2 . Storing at $32^{\circ} \mathrm{C}$ caused a fairly uniform change in the chromatographic pattern, although changes following storage as a 5 per cent solution were somewhat less drastic; storing at $32^{\circ} \mathrm{C}$ in the dry state seemed particularly deleterious (Figure 1 and Table I).

Paper electrophoresis of concentrated fractions revealed no difference between regions 1 and 2, both migrating like the albumin in freshly drawn plasma. Region 3, even when highly concentrated, appeared as a diffuse smear between the origin and the position of $\alpha_{2}$-globulin. In samples showing type I elution profiles, any $\alpha$-globulin present began to come off the column toward the end of region 2 .

The protein in region 1 of all preparations had a sedimentation coefficient closely approximating the accepted value for human albumin (Table II). That this material was relatively homogeneous was evidenced by the slow spreading of the boundary during the course of ultracentrifugation.

Ultracentrifugation of all samples from region 2 revealed at least two boundaries (Table II). In materials with type IV chromatographic patterns, three boundaries were seen. In all of these, the slowest boundary had a sedimentation coefficient very close to that of region 1 . The sedimentation coefficients of the next boundary were by no means constant among the various preparations, ranging from 5.90 to $7.00 \mathrm{~S}$ (Table II). In the two type IV patterns, the third ultracentrifugal peak had a still higher sedimentation coefficient.

TABLE I

Summary of chromatographic elution profiles

\begin{tabular}{|c|c|c|c|c|c|}
\hline \multirow[b]{2}{*}{ Lot } & \multirow[b]{2}{*}{ Source* } & \multirow[b]{2}{*}{$\begin{array}{l}\text { Per cent } \\
\text { protein }\end{array}$} & \multirow{2}{*}{$\begin{array}{l}\text { Years } \\
\text { stored }\end{array}$} & \multicolumn{2}{|c|}{$\begin{array}{c}\begin{array}{c}\text { Type of elution } \\
\text { pattern }\end{array} \\
\end{array}$} \\
\hline & & & & $\begin{array}{l}5^{\circ} \mathrm{C} \\
\text { storage }\end{array}$ & $\begin{array}{l}32^{\circ} \mathrm{C} \\
\text { storage }\end{array}$ \\
\hline $\begin{array}{l}\text { Fresh fraction V, never heated } \\
\text { Fresh commercial albumin } \\
203 \\
203 \\
204 \\
205 \\
204 \\
201\end{array}$ & $\begin{array}{c}C W \\
C W \\
C W \\
C W \\
C W+I D \\
\text { ID } \\
C W+I D \\
C W\end{array}$ & $\begin{array}{l}\text { Dry } \\
25 \\
25 \\
5 \\
25 \\
25 \\
\text { Dry } \\
25\end{array}$ & $\begin{array}{r}0 \\
0 \\
5 \\
5 \\
5 \\
5 \\
5 \\
10\end{array}$ & $\begin{array}{l}\text { I } \\
\text { I } \\
\text { I } \\
\text { I } \\
\text { II } \\
\text { II } \\
\text { II } \\
\text { II }\end{array}$ & $\begin{array}{l}\text { III } \\
\text { II } \\
\text { III } \\
\text { III } \\
\text { IV } \\
\text { IV† }\end{array}$ \\
\hline
\end{tabular}

* $\mathrm{CW}=$ citrated whole plasma ID = ultraviolet-irradiated, dried plasma.

$\dagger$ Stored 5 years at $5^{\circ} \mathrm{C}$, then 5 more years at $32^{\circ} \mathrm{C}$. 
TABLE II

Ultracentrifugal analyses of chromatographic fractions

\begin{tabular}{|c|c|c|c|c|c|c|c|}
\hline \multirow[b]{2}{*}{ Lot } & \multirow[b]{2}{*}{ Source* } & \multirow{2}{*}{$\begin{array}{l}\text { Years } \\
\text { stored }\end{array}$} & \multirow{2}{*}{$\begin{array}{l}\text { Storage } \\
\text { temp }\left({ }^{\circ} \mathrm{C}\right)\end{array}$} & \multirow{2}{*}{$\begin{array}{l}\text { Chro- } \\
\text { matog. } \\
\text { pattern }\end{array}$} & \multicolumn{3}{|c|}{ S20 values in chromatographic regions $\dagger$} \\
\hline & & & & & Region 1 & Region 2 & Region 3 \\
\hline \multirow[t]{2}{*}{$\begin{array}{l}\text { Fresh } \\
\text { fraction V }\end{array}$} & $\mathrm{CW}$ & 0 & & I & 4.18 & $\begin{array}{l}4.44,7.13 \\
(89 \%),(11 \%)\end{array}$ & \multirow{3}{*}{$\begin{array}{l}4.19,7.54,29.4 \\
(83 \%),(13 \%),(4 \%)\end{array}$} \\
\hline & & & 5 & I & 4.05 & \multirow{2}{*}{$\begin{array}{l}4.05,5.90 \\
(87 \%),(13 \%) \\
4.19,6.68 \\
(79 \%),(21 \%)\end{array}$} & \\
\hline \multirow[t]{2}{*}{203} & $\mathrm{CW}$ & 5 & 32 & III & 4.15 & & \\
\hline & \multirow{3}{*}{$C W+I D$} & \multirow{3}{*}{5} & 5 & II & 4.12 & \multirow{3}{*}{$\begin{array}{l}4.40,6.73 \\
(80 \%),(20 \%) \\
4.09,6.36 \\
(80 \%),(20 \%) \\
7.27>7.00>3.44\end{array}$} & \multirow{3}{*}{$\begin{array}{l}4.30,6.44,22.7 \\
(67 \%),(6 \%),(29 \%) \\
4.55,9.62,33.4,(80) \\
(59 \%),(11 \%),(31 \%),(t r .\end{array}$} \\
\hline \multirow[t]{2}{*}{204} & & & 32 & III & 4.15 & & \\
\hline & & & 32 Dry & IV & 4.12 & & \\
\hline \multirow[t]{2}{*}{201} & \multirow[t]{2}{*}{$\mathrm{CW}$} & \multirow[t]{2}{*}{10} & 5 & II & 4.20 & $\begin{array}{l}4.37,6.64 \\
(76 \%),(24 \%)\end{array}$ & \\
\hline & & & $32 \ddagger$ & IV & 4.15 & $\begin{array}{l}4.19,6.11,8.34 \\
(78 \%),(22 \%), \text { (tr.) }\end{array}$ & \\
\hline
\end{tabular}

* $\mathrm{CW}=$ citrated whole plasma ID = ultraviolet-irradiated, dried plasma.

$\dagger \mathbf{s}_{20}$ values are in $\mathrm{S}$; figures in parentheses are relative proportions of the appropriate components.

$\ddagger$ Five years at $5^{\circ} \mathrm{C}$ followed by 5 years at $32^{\circ} \mathrm{C}$.

Three region 3 samples were also ultracentrifuged. In all cases at least three boundaries were noted, one with a sedimentation coefficient greater than $22 \mathrm{~S}$, and one with that of albumin. The relative proportion of fast component seemed to increase with increased change in the chromatographic pattern, types II and III having more than type I (Table II). A similar situation seemed to obtain in the case of the components from region 2 having sedimentation coefficients of 5.90 to 7.00 $\mathrm{S}$. The increases in both cases were most marked between types I and II.

\section{DISCUSSION}

A number of workers (6-9) have utilized chromatography on modified cellulose to investigate macromolecular changes; two of these $(7,8)$ employed continuous gradient elution systems. Keller and Block (9) reported that when bovine mercaptalbumin was chromatographed on DEAE cellulose, the material with higher $s_{20, w}$ values was eluted at higher ionic strengths than were those components having $s_{\mathbf{2 0}, \mathbf{w}}$ values of albumin. In our studies, components with higher $s_{20}$ values consistently came off the column in regions 2 and 3.

The present chromatographic work indicates that the extent of changes occurring in albumin during storage are dependent on both the nature of the material used for preparation, and the conditions of storage. The albumins which were chromatographically most similar to fresh fraction $\mathrm{V}$ were those prepared from liquid citrated whole plasma and stored at $5^{\circ} \mathrm{C}$. The concentration during storage seemed to be of less significance, at least during the first five years.

The fact that when chromatographically detectable changes were seen, they always appeared in the same region of the pattern suggested that the changes were of a similar nature and progressed with the degree of protein alteration. However, a lack of uniformity in the nature of these changes is indicated by the wide range of sedimentation coefficients of the components with $s_{20}$ greater than $5.9 \mathrm{~S}$. The only consistent trend seems to be the appearance of more rapidly sedimenting material in chromatographic regions 2 and 3 as the elution profile type progresses.

Concomitant use of both chromatography and ultracentrifugation permitted measurement of components not observed by using either technique alone on whole commercial albumin. This was shown in parallel measurements on both $5^{\circ}$ and $32^{\circ} \mathrm{C}$ samples of lot 204 . Full studies of albumin storage using electrophoresis, viscosity, and other methods will be reported in the future. The indications are, however, that the chromatographyultracentrifugation technique is at least as sensi- 
tive for detection of protein change as other commonly used methods, and is probably more sensitive than most.

\section{SUMMARY}

Studies by means of chromatography on DEAE cellulose and subsequent ultracentrifugation were carried out on commercial human albumin preparations stored under various conditions for at least five years. Albumins prepared from citrated whole plasma and stored for five years at $5^{\circ} \mathrm{C}$ showed minimal difference in chromatographic behavior from fresh albumin samples. Those stored for ten years, stored at $32^{\circ} \mathrm{C}$, or prepared from ultraviolet-irradiated dried plasma demonstrated more marked differences on chromatography, namely, increased amounts of material appearing later in the elution patterns. This latter material contained components with sedimentation coefficients greater than $5.9 \mathrm{~S}$, the amounts of which seemed to increase with increasing change in the chromatographic profile. In this study coordinated use of both chromatography and ultracentrifugation provided an extremely sensitive method for detecting protein alteration.

\section{ACKNOWLEDGMENT}

The authors wish to thank Mr. Nelson Roberts for skilled technical assistance and Dr. Robert Woodworth for some of the powdered cellulose.

\section{REFERENCES}

1. Cohn, E. J., Strong, L. E., Hughes, W. L., Jr., Mulford, D. J., Ashworth, J. N., Melin, M., and Taylor, H. L. Preparation and properties of serum and plasma proteins. IV. A system for the separation into fractions of the protein and lipoprotein components of biological tissues and fluids. $\mathrm{J}$. Amer. chem. Soc. 1946, 68, 459.

2. Murray, R., and Diefenbach, W. C. L. Effect of heat on the agent of homologous serum hepatitis. Proc. Soc. exp. Biol. (N. Y.) 1953, 84, 230.

3. Peterson, E. A., and Sober, H. A. Chromatography of proteins. I. Cellulose ion-exchange adsorbents. J. Amer. chem. Soc. 1956, 78, 751.

4. Sober, H. A., and Peterson, E. A. Protein chromatography on ion exchange cellulose. Fed. Proc. 1958, 17, 1116.

5. Peterson, E. A., and Sober, H. A. Variable gradient device for chromatography. Analyt. Chem. 1959, $31,857$.

6. Kit, S. Comparative effects of heat on chromatography and ultra-violet absorption of deoxyribo- or ribonucleic acids. Nature (Lond.) 1959, 184, 36.

7. Cohen, S. Chromatographic behaviour of human albumin labelled with iodine-131. Nature (Lond.) 1959, 183, 393.

8. Fahey, J. L., and Steinfeld, J. L. Chromatographic differences between radioiodinated albumin preparations and normal human serum albumin. Proc. Soc. exp. Biol. (N. Y.) 1958, 97, 281.

9. Keller, S., and Block, R. J. Amino acid composition of the serum proteins. III. The chromatographic isolation of human and bovine serum albumins, and the amino acid composition of the fractions. Arch. Biochem. 1959, 85, 366. 